Artículo

\title{
Growth or stagnation? Well-being during the Spanish industrialization in Alcoy (1860-1910)
}

\author{
Daniel Gallardo-Albarrán* (D) \\ Wageningen University \\ José Joaquín García-Gómez D \\ Universidad de Almería
}

\section{ARTICLE INFO}

\section{Article history:}

Reception: 20 de julio de 2020

Acceptance: 15 de febrero de 2021

On-line: 14 de abril de 2021

\section{JEL classification:}

N3

J1

N9

H4

\section{Keywords:}

Industrialization

Health

Welfare

Spain

\begin{abstract}
A B S T R A C T
This article examines the effects of industrialization on overall well-being in Alcoy, a classic industrial town during Spanish economic modernization, by developing a utility-based indicator of welfare that combines detailed information on wages, health and inequality during the period 1860-1910. We find that aggregate male welfare rose by 40 percentage points, and that most of this improvement took place before 1877 . These gains were not equally distributed, since male workers in agriculture experienced long-term stagnation, while the well-being of industrial and service labourers rose substantially. We provide tentative calculations for female workers showing that their living standards did not stagnate during the last part of the 19th century. Furthermore, we quantify the implications of taking different age perspectives to measure well-being. We find that excluding the youngest part of the population from the calculations during the analyzed period underestimates welfare growth by more than 50 per cent.
\end{abstract}

(c) 2021 Asociación Española de Historia Económica

\section{¿Crecimiento o estancamiento? Bienestar durante la industrialización española en Alcoy (1860-1910)}

\section{R E S U M E N}

Este artículo estudia los efectos de la industrialización en el bienestar en Alcoy, una ciudad industrial modelo de la modernización económica española, desarrollando un indicador de bienestar basado en la utilidad, que combina información sobre salarios, salud y desigualdad durante el período 1860-1910. Encontramos que el bienestar masculino aumentó en 40 puntos porcentuales, y que la mayor parte de esta mejora tuvo lugar antes de 1877. Observamos que los trabajadores varones en la agricultura experimentaron un estancamiento, mientras que el bienestar de los trabajadores industriales y de servicios aumentó sustancialmente. Las estimaciones de bienestar para las trabajadoras muestran que su nivel de vida no se estancó a finales del siglo xix. Además, cuantificamos las implicaciones de considerar diferentes edades a la hora de medir el bienestar: al excluir a la parte más joven de la población de los cálculos subestimaríamos un crecimiento del bienestar de más de un 50\%.

(c) 2021 Asociación Española de Historia Económica

\footnotetext{
* Corresponding author: daniel.gallardoalbarran@wur.nl (Daniel Gallardo-Albarrán).
} 


\section{Introduction}

The industrial revolution has affected human lives more radically than probably any other event in human history. This process transformed the economic, demographic and social landscape of those countries that embraced the innovations and the dynamic character of a "revolution" that started in England. As other countries began to industrialize, the blessings and challenges that the industrial revolution posed for citizens' well-being also spread, especially concerning their material living standards and health ${ }^{1}$.

The Spanish case during the $19^{\text {th }}$ century is not an exception in this regard, since modest increases in income per capita were accompanied by low life expectancy levels for decades (Nicolau, 2005; Felice et al., 2016). This had negative consequences for the overall well-being of the population, as suggested by the stagnation of average stature -a commonly used measure of biological living standards- followed by a modest increase during the second half of the $19^{\text {th }}$ century (Martínez-Carrión, 2012). While informative of the national Spanish experience, these studies do not consider substantial intra-country geographic variation that is crucial to understand the drivers and actual impact of industrialization on citizens' well-being. An emerging body of literature is filling this gap and it has highlighted that differences in living standards across regions, as measured by anthropometric indicators, can be very significant (Cámara et al., 2019; Varea et al., 2019).

Our study provides a three-fold contribution to this literature by analysing the evolution of well-being in the city of Alcoy, a Spanish pioneer industrial city, during industrialization. First, we analyze historical well-being using a consumption equivalent measure of well-being drawing on state-ofthe-art techniques from welfare economics (Becker et al., 2005; Jones and Klenow, 2016). With this measure, we provide a so far unexplored view of well-being during the Spanish industrialization merging information on real wages, life expectancy and inequality using an expected utility framework. This approach complements earlier attempts to measure historical well-being using anthropometric indicators or the human development index, since we aggregate various components in a way that is consistent with standard economic theory (Nordhaus, 2003).

Second, the archival material of Alcoy is very comprehensive, which allows for a careful and thorough analysis of three key dimensions of well-being for a long time span: real wages, economic inequality and mortality. We put together new quantitative data of the sectoral structure of the labour force to construct a new real wage index that reflects the economic structure of the city, thus improving on earlier studies considering this city, such as García-Gómez (2015) and García-Gómez and Escudero-Gutierrez (2018). Moreover, we have improved the real wages series presented in these articles by creating a new consumer price index that includes novel information on the evolution of rental housing prices in different districts of the city. This important methodological change makes our historical price series more accurate, since housing represented approximately 9-15\% percent of workers expenses at the

\footnotetext{
${ }^{1}$ Some studies examining the impact of industrialization in England are Wrigley et al. (1997); Szreter and Mooney (1998); Komlos (1993) and Floud et al. (2011).
}

time (Barquín, 2019). Finally, we use detailed age-specific mortality rates to construct measures of life expectancy at age 15 . We then use this indicator in our welfare analysis along with life expectancy at birth to provide different welfare perspectives throughout this period.

Third, we examine the experience of one of the pioneer industrial cities in Spain that closely resembled other industrial areas of North-Western Europe. Already in the 1820s, Alcoy transitioned from the putting-out system to the factory system specializing in wool textiles, paper and metallurgy (Aracil and García Bonafé, 1974; Cuevas, 1999a, 1999b; Torró, 1994, 1996, 2000, 2004, 2020). As a result, the percentage of workers employed in industry was above 80 per cent at the beginning of the $20^{\text {th }}$ century ${ }^{2}$. Furthermore, the importance of Alcoy in the economic modernization of Spain and its challenges was recognised by the contemporaneous literature (Madoz, 1846; Martí, 1864; Real Academia de Medicina, 1879; Revenga, 1904); and the literature on Spanish industrialization (Nadal, 2003; Parejo, 2006; Comín, Hernández and Llopis, 2010). The substantial scholarly attention on Alcoy presents a further methodological advantage for our study, since we can test the plausibility and robustness of our new indicator with earlier metrics of living standards applied in the same context.

We calculate welfare levels aggregating utility flows derived from changes in real wages, life expectancy and inequality for various benchmarks between 1860 and 1910 . Our analyses present three main findings. First, our metric shows that longterm aggregate male welfare during the analyzed period increased by about 40 percentage points. We identified three well-differentiated phases: $1860-1877 ; 1877-1900$ and 19001910. The first exhibits a significant rise in welfare levels due to steady improvements in both health and purchasing power conditions. The second phase presents a sharp slowdown in welfare growth, since life expectancy reached a plateau between 1877 and 1900 due to urban congestion and overcrowding. Rising real wages and decreasing inequality were not sufficient to offset the negative contribution of health to overall well-being. The last phase is characterized by stagnation. Although health conditions improved again after 1900 as a result of important investments in urban infrastructures and a more egalitarian distribution of income within households, stagnant real wages hindered further welfare improvements. Concerning the well-being of female workers, our results show that welfare followed the broad patterns discussed above with the exception that female living standards did not stagnate during the last part of the $19^{\text {th }}$ century. Second, our results point to substantially different welfare trajectories among workers. Whereas agricultural workers did not see increases in living standards during the period 1860-1910, the well-being of industrial and service labourers rose substantially. Our last finding shows that most welfare improvements disappear when we replace life expectancy at birth in our indicator for life expectancy at age 15 . The calculations imply that excluding the youngest part of the population from the calculations during the analyzed period underestimates overall welfare growth by more than 50 per cent.

This article is related to a literature studying Spanish historical well-being using the Human Development Index (Es-

2 Estadística obrera 1914. Municipal Archive of Alcoy. 
cudero and Pérez Castroviejo, 2010; Escudero and Simón, 2012). We provide a new perspective to these studies applying a novel utility-based welfare metric. In addition, our study adds new insights to earlier historical research applying measures grounded in standard economic theory -e.g. Williamson (1984), Voth (2004) and Gallardo-Albarrán (2019)- using detailed sector-specific data on real wages and age-specific health measures ${ }^{3}$.

\section{Measuring well-being}

The definition of well-being has drawn the attention of a large number of scholars since at least Aristotle ("eudaimo-

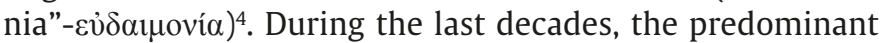
approach has been the use of real income, which implicitly reflects the preferences of individuals to satisfy their wants. Income or per capita income was considered the indicator of well-being par excellence until well into the 1960s. However, some of its drawbacks generated an increasing body of literature that criticized how this indicator does not properly account for (among others) life expectancy, education, health, working conditions, leisure, environmental damage or non-market activities (Sen, 1987; Stiglitz et al., 2009; Fleurbaey and Blanchet, 2013). To deal with some of these critiques, a different branch of the literature built more encompassing indices considering non-monetary aspects, such as the Human Development Index (HDI), that aggregates information on the dimensions of income, health and education. However, despite this index has been widely used in the literature, there is controversy about its weighting scheme and implied trade-offs between its dimensions (Nordhaus, 2003; Klugman et al., 2011; Ravallion, 2012).

We follow a different multi-dimensional approach to study the long-run evolution of well-being in Alcoy considering information on income, health and inequality ${ }^{5}$. We draw on standard economic theory to create a composite indicator that allows us combining these three dimensions, instead of looking at them separately. In particular, we follow the methodology proposed by Jones and Klenow (2016) using an expected utility framework. This approach is comparable to earlier work by Nordhaus (2003), Becker et al. (2005) and Gallardo-Albarrán (2019). In following this line of work, instead of that of the HDI, we do not claim that we provide a definitive answer on how to measure historical well-being. As we will show below, this methodological framework, as any multidimensional index, is sensitive to substantial changes of the calibration procedure. However, we think that its strong methodological foundation on expected utility theory provides a new and useful perspective to compare living standards in Alcoy. We begin, drawing on Jones and Klenow (2016), by defining the welfare of an individual:

\footnotetext{
${ }^{3}$ See Prados de la Escosura (2015) for a different approach on measuring human development.

${ }^{4}$ Aristotle (1990).

${ }^{5}$ We acknowledge that these are not the only aspects of well-being that matter to citizens. For instance, citizens valued environmental changes, social security or the political environment at the time. Nevertheless, we decided to focus on income, health and inequality due to methodological and data availability considerations. We discuss these in detail below as well as their implications for our analysis.
}

$$
U(\lambda)=E \sum_{a=1}^{110} \beta^{a} u\left(\lambda C_{a}\right) S(a),
$$

where well-being $(U)$ is given by consumption flows (C) discounted at a certain rate to account for preferences concerning present and delay satisfaction $(\beta)$, and at different ages (a) weighted by the probability of surviving up to a certain age (S). It is important to highlight that our indicator differs in an important aspect with Jones and Klenow (2016), since we do not consider changes in welfare attributed to leisure developments. The motivation for this is data driven, since we could not construct a consistent working time series during the analyzed period. Anecdotal evidence suggests that the number of working hours exceeded 9 and 10 hours per day. For this reason, the main demand of the internationalist revolutionaries in 1873 was to lower such long working days to 8 hours per day. A few decades later, conditions seem to have improved since the municipality claimed in 1913 that construction workers working on public projects would be employed for 8 hours a day and a 60-hour week was approved by the government (Real Decreto de 24 de agosto de 1913). Although contemporaries saw this as a factor pushing down the well-being of the working classes ${ }^{6}$, the suggestive evidence we had on working time is not enough to accurately infer its welfare impact in Alcoy during the late $19^{\text {th }}$ century.

To compare utility changes over time, we compute a consumption-equivalent index $(\lambda)$ using 1910 as the benchmark year for comparisons. This is equivalent to answering the following question: by which factor $(\lambda)$ do we have to adjust an individual's consumption in Alcoy in a given year so that his utility level is the same as in 1910 ? Formally, we can express this as follows:

$$
U_{1910}(1)=U_{t}\left(\lambda_{t}\right) \text {. }
$$

In this equation, the individual's consumption in a certain year $t$ is adjusted by $\lambda_{t}$ so that she is as well off as in 1910 with a different level of consumption and health status, as measured by survival probabilities.

We extend Equation 1 in various ways. First, we choose a logarithmic functional form for consumption and assume consumption is lognormally distributed so that in our expected utility framework: $E[\log C]=\log c-\sigma^{2} / 2$, where $c$ and $\sigma^{2}$ are the mean and variance of log consumption, respectively. This allows us to include a measure of inequality $\left(\sigma^{2}\right)$ in our framework, since assuming logarithmic utility in consumption results in risk aversion (Atkinson, 1970). Intuitively, greater inequality contributes negatively to our welfare indicator, since it increases the risk or uncertainty of realizing the mean value of the consumption distribution. To be sure, we do not claim that this mechanism captures the complex interaction of inequality with other dimensions of well-being, or with living standards in general. For instance, Piketty (2014) highlights that income and capital accumulation at the top of the distribution

\footnotetext{
${ }^{6}$ In 1890 , the construction workers' union claimed that excessive working hours was the main source of physical discomfort of the working class. Revenga (1903) also mentioned that children aged 10 or 12 worked extremely long shifts.
} 
reflects the concentration of political and economic power in the hands of a small elite. Stiglitz (2012) links inequality with disenfranchisement and undemocratic practices. Our article takes a narrower perspective on this topic and examines, as a first approximation, how inequality influenced welfare using an expected-utility framework. In addition, we choose a value of one for $\beta$ and rewrite survival rates so that we obtain life expectancy at birth: $e_{0} \equiv \sum_{\mathrm{a}} S(a)$. Assuming there is no discount factor implies a more egalitarian view of living standards throughout people's life, since consumption flows across ages have the exact same weight. In addition, this choice results in a much more intuitive way to measure well-being in Alcoy, which equals the expected value of consuming a certain bundle of goods and services observed in a given year ${ }^{7}$. Formally:

$$
U_{t}=e_{t}\left(\bar{u}+\log c_{t}-\frac{\sigma_{t}^{2}}{2}\right)
$$

Equation 3 shows how utility levels are obtained in year $t$ by combining information on life expectancy $\left(e_{t}\right)$, material living standards $\left(\log c_{t}\right)$ and inequality $\left(\sigma_{t}^{2}\right)$. We then calculate our consumption equivalent measure of welfare in additive form as follows:

$$
\begin{aligned}
\log \left(\lambda_{t}\right)= & \frac{e_{t}-e_{1910}}{e_{t}}\left(\bar{u}+\log \left(c_{1910}\right)-\frac{\sigma_{1910}^{2}}{2}\right) \\
& +\log \left(c_{t}\right)-\log \left(c_{1910}\right) \\
& -\frac{1}{2}\left(\sigma_{t}^{2}-\sigma_{1910}^{2}\right) .
\end{aligned}
$$

The first right-hand-side component of this equation measures the welfare contribution of life expectancy, which is weighted by utility flows in 1910 . This is the result of employing the compensating variation of our metric, instead of the equivalent variation that uses a changing base year over time. This distinction matters little in our context since, as shown by Gallardo-Albarrán and de Jong (2021), changing the base year for the calculations barely affects the calculations. The last two elements of Equation 4 measure the percentage change (in logarithmic points) of consumption over time, and welfare impact of inequality.

Before we can use equation 4 to compute welfare levels over time $\left(\lambda_{t}\right)$, we need to calibrate $\bar{u}$. This constant captures the idea that a year of life is valuable beyond the mere enjoyment of consumption. We choose a value for $\bar{u}$ in line with Jones and Klenow (2016) and Gallardo-Albarrán (2019) by assuming a benchmark value of statistical life (VSL) of \$6 million. Then, we adjust this value to better reflect workers' perspectives in our particular historical context using a VSL elasticity. The intuition behind this procedure is grounded on the finding that the mortality premium of hazardous jobs, which gives an indication of the importance of health relative to income by workers, has not remained constant over time. In fact, this premium was much lower in history which suggests that using a current-day VSL to calibrate our model would result in an overestimation of the relative importance of health in our indicator (Fishback,

\footnotetext{
7 The discount factor does not have a significant impact on the calculations, as shown by Gallardo-Albarrán (2019) in Appendix D.
}

1992; Costa and Kahn, 2004). We use the VSL elasticity proposed by Costa and Kahn (2004) to obtain a VSL for 1910, which results in $\bar{u}=1.35^{8}$. It is important to note that this elasticity refers to American workers during the period 1940-1980. While we acknowledge that ideally we would use information on workers preferences from Alcoy, or Spain, such information is not available to the best of our knowledge. In any case, we show below that our results are robust to changes in the VSL to calibrate our indicator.

\section{Data}

For our welfare metric, we need data on life expectancy, consumption and inequality. For life expectancy (and later life expectancy at age 15), we draw on the life tables compiled by García-Gómez (2016) for multiple key benchmarks during the industrialization period in Alcoy: 1860, 1877, 1900 and 1910.

We measure material living standards (consumption in equation 4) with detailed data on male and female real wages drawing on nominal wages compiled by García-Gómez (2015) and Beneito and García-Gómez (2019). For the period 1860-1880, these were taken from the records of the Real Fábrica de Paños, account books of the civil hospital, municipal budgets, contemporary newspapers and labor reports by the municipality. For the remaining years until 1910, nominal wages were obtained from libros padrones de cédulas personales and collective agreements.

The richness of the sources allowed for constructing sector-specific wage indices: agriculture, industry and services ${ }^{9}$. In the case of female wages, though, a consistent series for agriculture could not be constructed due to data availability. We deflated nominal wages using a single consumption price index drawing on García-Gómez (2015), which has been updated with novel information on rental housing prices. This increased substantially the reliability of the consumer price index which now reflects accurately how the affordability of rental housing varied over time. Using a single price index to deflate all wage series, we mostly focus on differences in purchasing power over time, since relative differences cannot be measured accurately. We construct an aggregated wage series using information on employment distribution by sector from several sources. The first is the Interrogatorio de $1803^{10}$ providing information on the occupations of the inhabitants (including the unemployed). The second source is the Estadística industrial de 1856. Third, the Estadística obrera de 1914 that includes a detailed breakdown of the occupations in Alcoy. Although limited, these data allows us to obtain employment shares for the first time during the analyzed period by interpolating between benchmarks ${ }^{11}$.

\footnotetext{
${ }^{8}$ Following other studies in the literature, we use national data in our calibration procedure on mortality rates and income per capita. Thus, our estimate of the relative importance applies to the Spanish context. The calibration of our model implies a VSL that is 30 times GDP per capita in 1910. For comparison, VSLs applied in earlier studies focused on recent years assume values around 130 times GDP per capita in the United States.

${ }^{9}$ The series for industrial workers is an average of nominal wages of the manufacturing and building sector. An average of health and education comprises the services sector wage series.

10 Archivo Histórico Municipal de Alcoy (AMA). Legajo 5542.

${ }^{11}$ Between 1860 and 1910, the percentage of agricultural workers declined from 17 to virtually zero percent; from 60 to 86 percent in manufacturing; and from 24 to 14 percent in the service sector. These data are for men only, since such information is not available for the female labor market.
} 
Table 1

Various indicators of living standards in Alcoy, 1860-1910

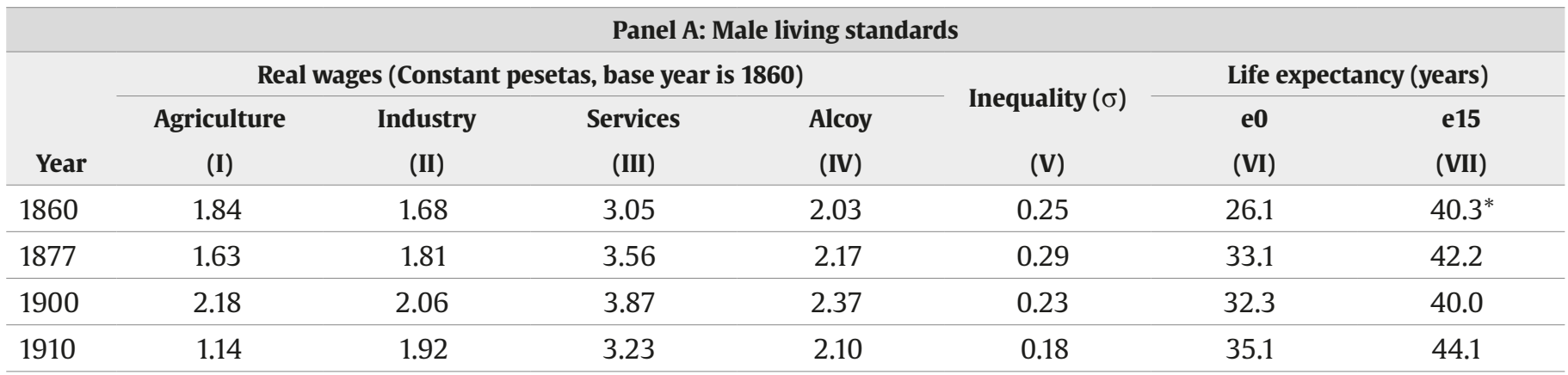

\begin{tabular}{|c|c|c|c|c|c|c|c|}
\hline \multicolumn{8}{|c|}{ Panel B: Female living standards } \\
\hline & Agriculture & Industry & Services & Alcoy & Inequality $(\sigma)$ & e0 & e15 \\
\hline 1860 & n.d. & 1.07 & 1.78 & n.d. & n.d. & 29.0 & $43.5^{*}$ \\
\hline 1877 & n.d. & 1.29 & 1.68 & n.d. & n.d. & 36.8 & 45.5 \\
\hline 1910 & 0.62 & 0.88 & 1.82 & n.d. & n.d. & 38.1 & 48.7 \\
\hline
\end{tabular}

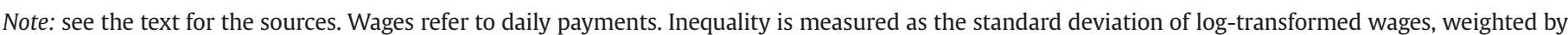

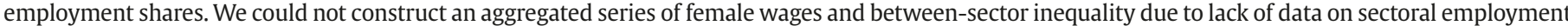

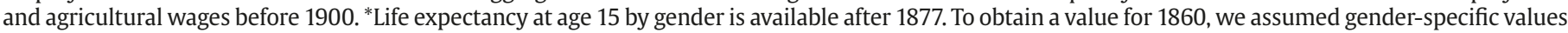
evolved according to life expectancy at age 15 for both men and women during the period 1860-1877.

We match the real wage information with that for life expectancy calculating five-year averages centered on the benchmarks for which life expectancy figures are available. This avoids the potential impact of year-to-year fluctuations on our real wage series.

Finally, we obtain a measure of wage inequality using the industry-specific wage series and employment shares mentioned above to calculate the variance of the (log) wage distribution.

Table 1 presents the evolution of living standards in Alcoy during the analyzed period using various indicators that will be later combined in our consumption equivalent measure of welfare. Beginning with male real wages (Panel A), we observe rising trends during the last decades of the $19^{\text {th }}$ century followed by a period of decline, especially in the case of agricultural workers. Farmers' real wages in 1910 were 40 percent lower than in 1860 (column I). Turning to wages in the service sector (column III), we observe that these are higher than in the rest of the economy throughout analyzed period. Some of these occupations in the health sector include doctors, nurses, midwifes, doormen (caretakers) or cooks. For the education sector, the sources include teachers (in a wide range of positions and incomes), caretakers or cleaners. If we consider the aggregated series for Alcoy (column IV), we find the same patterns as for the sector-specific series: improving purchasing power until 1900, and then a sharp decrease. The worsening of living standards after the turn of the $20^{\text {th }}$ century was so remarkable that average male wages by the end of the period were lower than in 1877. This period of decline was not the result of lower nominal wages, but rather an almost 50 percent increase of the price deflator due to rising housing prices as a result of uncontrolled migration. The prices of other items (e.g. sugar, milk, fish and salty codfish) increased, but with the exception of codfish, all of them weighted little in the consumption basket (García-Gómez, 2013).

Panel B of table 1 shows the evolution of female wages. We could not construct a comparable female wage index as we did for men (column IV), because we lack data on the employment structure of female workers and agricultural wages are not available before 1900. Similarly, we refrained from calculating between-sector wage inequality due to lack of data (column $\mathrm{V})$. However, the available evidence allows us to track the evolution of material living standards since 1860 in the secondary and tertiary sector that followed the same trajectories discussed above (i.e. increasing pattern until 1900 and a sharp decline afterwards), although at lower levels as documented by Beneito and García-Gómez (2019).

If we consider the distribution of wages, we observe a different development. Male wage inequality (Panel A, column V) was on the rise during the 1860s and 1870s, but it declined steadily to the lowest level of the period in the subsequent decades. Consequently, we find that declining material living standards after 1900 went hand in hand with higher levels of equality. Interestingly, this seems to suggest that convergence towards poverty or lower wages was the dominant pattern in the local labor market. Although more detailed data on the distribution of income within sectors would be needed to confirm this suspicion.

If we turn to health as measured by life expectancy at birth, we obtain a somewhat different picture. The health status of 
the male and female population in Alcoy exhibits an increasing trend over most of the period with an increase in life expectancy from 26 to 35 years in the case of men, and 29 to 38 years in the case of women (Table 1, column VI). Improvements in labor conditions, better nutrition and, above all, the consolidation of the sanitary reform in the last years of the 19th century are considered the most important reasons of this phenomenon (García-Gómez and Salort, 2014). Comparing the trends observed for wages and life expectancy, we can see that these move in opposite directions in two sub-periods. The first is the period 1877-1900 in which the rise in wages is followed by declining life expectancy. During the period 1877 to 1900 , the economy of Alcoy experienced a modernization process with the mechanization of weaving, the diffusion of steam energy and increasing migration inflows. These years were characterized by unhealthy working, living and environmental conditions resulting from the industrial system, poorly-managed urbanization and the non-intervention of the public sector to mitigate the market failures generated by the industrialization process (García-Gómez, 2016; García-Gómez and Puche, 2016). The second period comprises the early $20^{\text {th }}$ century and it is characterized by improving health while wages drop dramatically. As a result, the pessimistic picture portrayed by real wages during this sub-period has to be weighed against declining mortality.

In the second part of our analysis, we will use a different perspective to value health improvements using life expectancy at age 15. This health indicator (last column of Table 1), contrary to life expectancy at birth, exhibits a much lower increase and thus a more pessimistic development. It increased during the first two decades of the analyzed period and then slightly declined until 1910. This development lines up well with the first stage of the epidemic transition that took place in the occidental countries mainly during the $19^{\text {th }}$ century.

\section{Results}

\subsection{Main Results}

The study of individual indicators of living standards does not necessarily convey a unanimous picture about the evolution of broader well-being. This is a point that was already made for the British case by Crafts (1997) and Voth (2004). Our case study shows this quite vividly, since material living standards, inequality and health follow disparate developments during a period of intense industrializing. To understand how these various components contribute to overall welfare, we now turn to our consumption equivalent welfare metric presented in Table 2. Beginning with the aggregated male series for Alcoy (Panel A, column I), we find a significant increase during the analyzed period, since our welfare index exhibits an increase from 60 to 100 (the base year is 1910). This represents a 66 percentage increase, as welfare levels by 1910 were two thirds higher than in 1860 . This rise did not take place steadily over time Our index reveals a substantial improvement during the third quarter of the $19^{\text {th }}$ century and a modest increase until 1900 followed by a decade of stagnation. Thus, we can divide the analyzed period into three sub-periods with different consequences for workers in Alcoy: 1860-1877 (growth), 1877-1900 (slowdown) and 1900-1910 (stagnation).

In the remaining columns of table 2 , we provide sector-specific welfare indices using the wage series from table 1 . Although we do not have sector-specific information for health and inequality, these indices reveal the importance of using disaggregated data to analyze well-being over long periods of time. First, we find that the long-term living standards of agricultural workers stagnated (column II), while those for their counterparts in industry and services improved significantly (column III and IV). This large relative decline did not have a significant effect on the aggregated series, since the economic importance of this sector in the city had been declining for decades due to its specialization in the textile industry. Given that the other dimensions of well-being (i.e. health and inequality) experienced marked improvements, the worsening living conditions of the few agricultural workers can be explained by the substantial drop in purchasing power. This came as a result of lower nominal wages that declined about 25 percent as well as rising living costs. An implication of our results is that well-being for these workers stagnated between 1860 and 1910, whereas real wage developments imply a clear a 60-percent decline in living standards (Table 1, column I of Panel A).

Second, contrary to the series for agriculture and services, welfare levels in industry did not decline after 1900, despite the erosion of purchasing power during this period. Consequently, our index implies that industrial workers experienced the largest improvement in well-being between 1860 and 1910. Certainly, our calculations do not include more qualitative aspects of working conditions and a complete account of workers' living standards should take this into account in the future.

\section{Table 2}

Welfare trends in Alcoy, 1860-1910 (1910=100)

\begin{tabular}{rrrrr}
\hline \multicolumn{5}{c}{ Panel A: Male living standards } \\
& & \multicolumn{3}{c}{ By sector } \\
\cline { 3 - 5 } & Alcoy & Agriculture & Industry & Services \\
Year & (I) & (II) & (III) & (IV) \\
\hline 1860 & 60 & 100 & 54 & 59 \\
\hline 1877 & 93 & 128 & 85 & 99 \\
\hline 1900 & 99 & 168 & 95 & 106 \\
\hline 1910 & 100 & 100 & 100 & 100 \\
\hline
\end{tabular}

\begin{tabular}{ccccc}
\hline \multicolumn{5}{c}{ Panel B: Female living standards } \\
& & \multicolumn{3}{c}{ By sector } \\
\cline { 3 - 5 } & Alcoy & Agriculture & Industry & Services \\
Year & (I) & (II) & (III) & (IV) \\
\hline 1860 & n.d. & n.d. & 79 & 64 \\
\hline 1877 & n.d. & n.d. & 137 & 86 \\
\hline 1900 & n.d. & 152 & 177 & 133 \\
\hline 1910 & n.d. & 100 & 100 & 100 \\
\hline
\end{tabular}

Note: see Table 1 for the sources. We used equation 4 for the calculations. For men (Panel A), the sector-specific series use the same health and inequality information as the "Alcoy" series, while the wage index differs (see table 1). For women (Panel B), we could not construct an aggregated series of female wages and between-sector inequality due to lack of data on sectoral employment and agricultural wages before 1900 . Thus, we assumed that inequality (sigma in Table 1) followed the same trend as that for men. 
Panel B presents our welfare calculations for female workers. As mentioned earlier, we cannot construct an aggregated female series for the city because we lack detailed data on sectoral employment and agricultural female wages before 1900. In addition, we had to assume that wage inequality for men and women followed the same trend to construct our welfare series. With these qualifications aside, we find that the living standards of women rose substantially between 1860 and 1910, although to a lower extent than the improvement experienced by their male counterparts. More specifically, the welfare index of women employed in industry shows an increase from 79 to 100 , and that for services rises from 64 to 100. The female welfare series exhibit an important dissimilarity with our results for men, since they exhibit rapid growth during the last four decades of the $19^{\text {th }}$ century. However, an important part of these welfare gains, and similar to the experience of men, eroded during the first decade of the $20^{\text {th }}$ century.

To examine the factors driving long-term living standards in Alcoy, we provide a welfare decomposition in figure 1 using equation 4 . Here we focus on male workers since data are more complete. We compute the contribution of each dimension considered to welfare relative to 1910 , which is the reference year and thus zero by definition. For instance, if we consider the contribution of wages to well-being, we can see that rising workers' purchasing power during the period 1860-1900 added about 0.16 logarithmic points to overall welfare [0.12$(-0.04)]$. Taking the whole analyzed period into account, wages contributed to higher welfare by (roughly) four percentage points, since these were 0.036 logarithmic points lower in 1860 relative to 1910 (also see Table 1, column IV of Panel A). A different way to look at our results is as follows, using life expectancy as an example. Figure 1 shows that lower health outcomes in 1877 decreased welfare by eight percentage (log) points relative to 1910 .

Figure 1 shows that the long-term increase in well-being between 1860 and 1910 was due to a combination of improving material living standards, health and equality, though their relative contribution differed substantially. Rising wages and lower inequality added about 5 percentage points to overall living standards, while the nine-year increase in life expectancy added 0.46 logarithmic points. Thus, we can conclude that the main driver of well-being throughout the analyzed period was health gains.

If we consider short-term dynamics, we find three interesting developments. First, the large increase in welfare during the period 1860-1877 was due to a combination of improving purchasing power and health. In particular, the large increase in life expectancy (7.4 years, see Table 1, column VI of Panel A) contributed the most to welfare: 0.38 logarithmic points. Although inequality exhibited an increasing trend, its negative welfare contribution was very low, about one percentage point. Second, the slowdown of welfare growth after 1877 was due to stagnating and even worsening health levels. Our indicator suggests that overcrowding and lack of efficient sanitary infrastructures lowered welfare levels by three percentage points $[-0.116-(-0.081)]$. At the same time, increasing wages and, to a lower extent, decreasing inequality offset the negative contribution of health to well-being. Third, the stagnating picture portrayed by our measure during the 1900s was due to a combination of offsetting forces: improving health and equality, and worsening purchasing power.

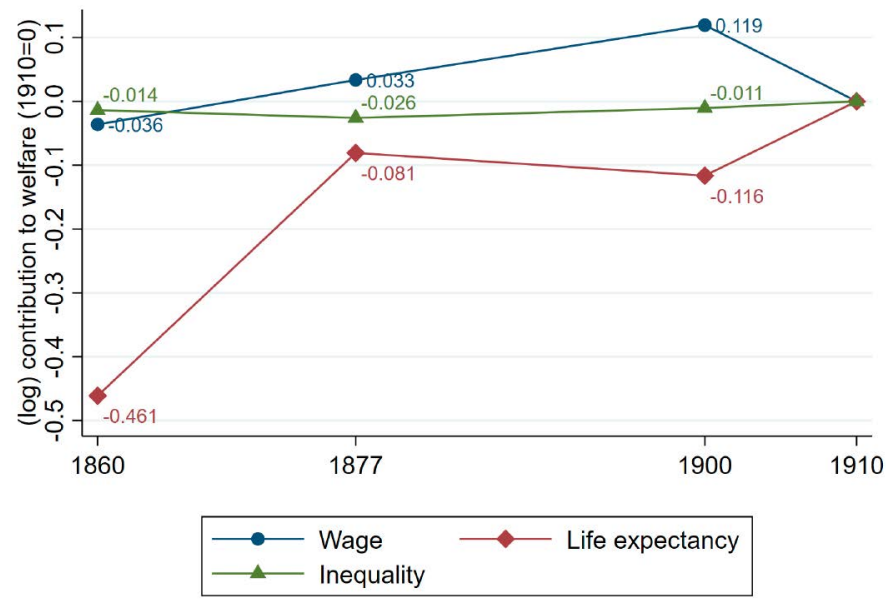

Figure 1. The contribution of wages, health and inequality to welfare in Alcoy, 1860-1910 (in logarithmic points).

Note: see Table 1 for the sources. We used equation 4 for the calculations.

The three-phase period we identify above lines up well with the historical context of Alcoy during industrialization. The mechanization of textile production processes that had primarily relied on labor input (e.g. spinning) increased manufacturing productivity and provided an incentive to transition from the putting out system to a modern industrial regime. Consequently, the demand for workers and their wages rose noticeably between 1860 and 1877 . The resulting improvement of purchasing power had a positive effect on the health status of the population, since the working class could afford a better diet in terms of quantity and quality. Estimates of calorie availability from hospital patients exhibit a rising trend since the mid- $19^{\text {th }}$ century, which was in part due to higher consumption of proteins (García-Gómez and Trescastro-López, 2017). In addition, spending on sanitary infrastructures per person increased slightly during the third quarter of the $19^{\text {th }}$ century and contributed to provide enough sanitary services for the growing population of the city (García-Gómez and Escudero, 2018).

The second phase comprises the period 1877-1900 and it is characterized by a slowdown in the rate of well-being growth. This was in part due to a series of political and economic crises in the city. Starting in in 1873-1874, the internationalist revolution depressed industrial production and, to some extent, wages until the late 1870s. This anarchist revolution was linked to the Spanish cantonalist movement during the First Republic and it brought to the streets ca. 10,000 workers demanding higher salaries and the 8-hour working day. The violent response of both factories' owners and the police resulted in 16 deaths and the burning of several factories. After many male workers were imprisoned or fired, family budgets reduced considerably because low payments to female labourers could not offset the income loss from traditional breadwinners (Coloma, 1959; Cerdà, 1980). Consequently, purchasing power deteriorated during various years of the 1870 s.

Around 1880 the industrialization process began a new phase in the city with the introduction of modern steam engines. These were applied in the textile sector to mechanize weaving. In addition, modern metallurgical and paper factories continued being established, which contributed to a much more diversified industrial sector. These developments contributed to higher nominal wages, especially after 1880 , and attracted a substantial amount of workers from neighboring 
provinces. However, rising rent prices as a result of immigration flows meant that real wages increased to a lower extent than nominal payments suggest.

A further important consequence of the rapid population growth after 1877 had to do with the uncontrolled expansion of the city (Revenga, 1904). In a few decades, population increased by about 30 percent and the newcomers could barely find a suitable place to live, since the city had few open spaces due to the low availability of suitable areas to expand (Beneito, 2003). Alcoy is located in a valley between several mountain ranges crossed by three rivers. Consequently, population density by the end of the $19^{\text {th }}$ century reached new heights (ca. 900 inhabitants per hectare). In working class neighbourhoods, the situation was even more dramatic with a population density of ca. 2,500 inhabitants per hectare (Dávila, 1993).

The last phase we identified in table 2 is marked by stagnation. As we mentioned earlier, rising demographic pressure within the city led to higher renting prices, which dramatically increased after 1900. Consequently, real wages experienced a sharp decrease, even though nominal wages were on the rise for workers in industry and services. Only after the First World War purchasing power would recover the levels exhibited in 1900.

In terms of public health, the situation improved substantially during the first decade of the $20^{\text {th }}$ century, when local authorities undertook a comprehensive set of reforms. Spending on sanitary expenses (in constant prices) almost doubled during the 1910s from 3.6 to 7 pesetas per capita (García-Gómez and Escudero-Gutierrez, 2018) ${ }^{12}$. Furthermore, infant mortality declined due to health progress and a more egalitarian distribution of income within the family, especially benefitting children and elderly. During the analyzed period, families seemed to dedicate proportionally more to these groups as they earned more, reducing intra-household inequality (Beneito and García-Gómez, 2019). Finally, although our indicator does not directly capture changes in working conditions, these also influence health outcomes $^{13}$. The labour legislation improved substantially throughout the analyzed period as a result of political pressure from unions, left-wing political parties and social reformers ${ }^{14}$.

Until now, our indicator has implicitly taken the perspective of a newborn, since our measure of health is life expectancy at birth. In the following, we change this and analyze the welfare of adults by using life expectancy at age 15 . In this way, we gain insights on the impact of industrialization on welfare for adults exclusively. Table 3 repeats our earlier exercise taking this perspective, for both male and female workers in Alcoy. Beginning with the aggregated series for males (column I, Panel A), we find adults' welfare levels improved between 1860 and

\footnotetext{
12 These numbers capture local investment, since competences on sanitation and education were primarily the responsibility of municipalities.

${ }^{13}$ Life expectancy reflects various key elements of the standard of living, such as nutrition, working conditions, individual habits and environmental conditions (e.g. housing, pollution, etc.). Although the scope of this paper does not allow for a comprehensive consideration of all these factors, there is a lively economic history literature about the relative importance of these factors. See Floud et al. (2011) or Harris and Helgertz (2019) for an overview of these studies.

${ }^{14}$ Ley de 24 de julio de 1873 on working conditions in factories, workshops and mines, Ley de 26 de julio de 1878 about dangerous jobs for children, Real Decreto de 26 de junio de 1902 on the working day of women and children, Ley de 3 de marzo de 1904 introducing Sunday as a non-working day or Ley de 24 de agosto de 1913 establishing a maximum of 60 working hours per week in the textile sector.
}

1910, but the magnitude of this improvement is smaller (16 percentage points) than shown earlier. Consequently, we can conclude that both the adult and newborn perspectives result in rising welfare levels over the long term.

If we turn to sector-specific series (last three columns of Panel A), we find somewhat different results. Beginning with agricultural workers, the series show a marked decline during the analyzed period. Actually, welfare levels were consistently above 1910 levels in all years. As we discussed above, this was the result of a significant erosion of purchasing power after 1900 due to lower nominal wages and rising living costs. Workers in industry and services fared better, though to a lower extent than shown previously. For instance, the series for industry increased by 24 percentage points during the analyzed period, whereas our results taking the newborn perspective suggest a 46-percentage-point rise. Overall, our findings suggest that excluding the youngest part of the population from the calculations during the analyzed period underestimates overall welfare growth by more than 50 per cent.

\section{Table 3}

Welfare in Alcoy using life expectancy at age 15, 1860-1910 $(1910=100)$

\begin{tabular}{|c|c|c|c|c|}
\hline \multicolumn{5}{|c|}{ Panel A: Male living standards } \\
\hline \multirow[b]{2}{*}{ Year } & \multirow[b]{2}{*}{$\begin{array}{c}\text { Alcoy } \\
\text { (I) }\end{array}$} & \multicolumn{3}{|c|}{ By sector } \\
\hline & & $\begin{array}{c}\text { Agriculture } \\
\text { (II) }\end{array}$ & $\begin{array}{c}\text { Industry } \\
\text { (III) }\end{array}$ & $\begin{array}{c}\text { Services } \\
\text { (IV) }\end{array}$ \\
\hline 1860 & 84 & 140 & 76 & 82 \\
\hline 1877 & 95 & 130 & 87 & 101 \\
\hline 1900 & 97 & 164 & 93 & 103 \\
\hline 1910 & 100 & 100 & 100 & 100 \\
\hline \multicolumn{5}{|c|}{ Panel B: Female living standards } \\
\hline \multirow[b]{2}{*}{ Year } & \multirow[b]{2}{*}{$\begin{array}{c}\text { Alcoy } \\
\text { (I) }\end{array}$} & \multicolumn{3}{|c|}{ By sector } \\
\hline & & $\begin{array}{c}\text { Agriculture } \\
\text { (II) }\end{array}$ & $\begin{array}{c}\text { Industry } \\
\text { (III) }\end{array}$ & $\begin{array}{c}\text { Services } \\
\text { (IV) }\end{array}$ \\
\hline 1860 & n.d. & n.d. & 102 & 82 \\
\hline 1877 & n.d. & n.d. & 130 & 82 \\
\hline 1900 & n.d. & 145 & 168 & 127 \\
\hline 1910 & n.d. & 100 & 100 & 100 \\
\hline
\end{tabular}

Note: see Table 1 for the sources and Table 2 for the calculation procedures. The only difference between these results and those in Table 2 is that we use life expectancy at age 15 to measure changes in health.

Next, we provide a breakdown of our indicator to examine the factors accounting for welfare changes over the long run in Figure 2. By definition, the main difference between this exercise and that presented in Figure 1 concerns the health dimension, since we use life expectancy at age 15 . However, it is instructive to compare the relative importance of each well-being dimension in determining overall welfare levels over time. Two points are worth highlighting. First, health improvements contribute to welfare gains before 1877 ( $0.06 \log$ points), although to a much lower extent than considering life expectancy at birth (0.38 log points). Second, the worsening of urban living condi- 
tions due to overcrowding and lack of proper sanitary services seem to have impacted more negatively on adults and reduced well-being during the last quarter of the $19^{\text {th }}$ century by about 8 percentage points. This offset almost completely any improvements coming from higher wages and lower inequality.

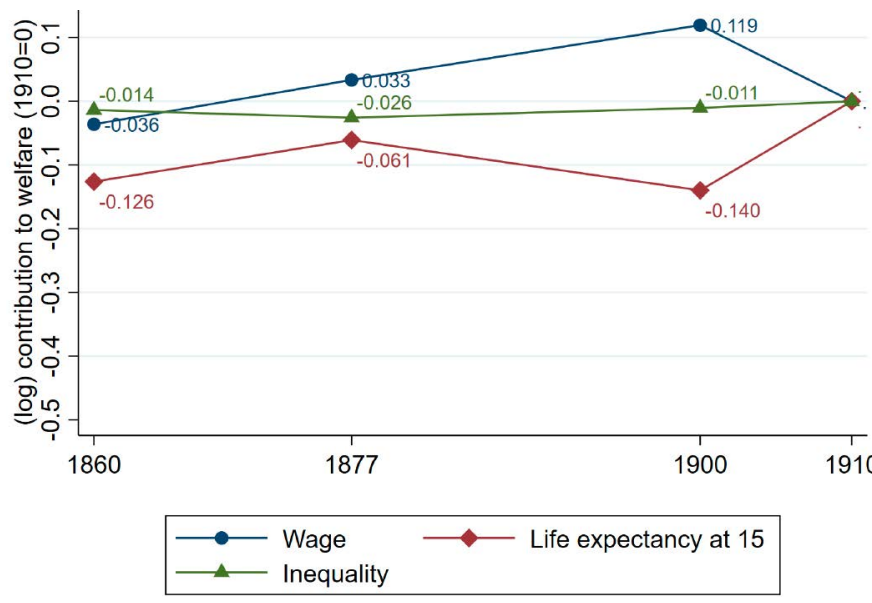

Figure 2. The contribution of wages, health and inequality to welfare taking an adult's perspective, 1860-1910 (in logarithmic points).

Note: see Table 1 for the sources. We used equation 4 for the calculations. The difference between this figure and Figure 1 is that here we measure changes in health with life expectancy at age 15.

The results in this section have important implications for the field of well-being measurement beyond our case study. First, we think taking different age perspectives to evaluate society's welfare is crucial to understand its drivers. The case of Alcoy shows that employing this strategy for the analysis of health changes has important consequences for our welfare index. These consequences will likely vary across countries and time, since the demographic transition has proceeded at different time and pace throughout the world. Furthermore, we think that the various perspectives we offer in this article are not substitutes, but complementary. Thus, there is not a reason a priori for choosing one approach over the other. Taking the perspective of a newborn is informative about the family as a whole, since (i) relatives do care about her well-being; (ii) it conveys information about the prevalence of infectious diseases that are deadly to children and affect adults' morbidity levels; and (iii) they represented an important share of the population during the late $19^{\text {th }}$ and early $20^{\text {th }}$ century. The census population reports that children below age 5 (15) represented 16 (37) and 10 (34) percent of the total population in 1860 and 1910, respectively ${ }^{15}$. Thus, simply ignoring their experience misses an important part of a society's welfare.

Second, concerns about the distribution of a particular aspect of living standards are crucial. Recent work on the national distribution of income has shown inequality was a common feature of 19th-century developed economies (Piketty, 2014; Milanovic, 2016). Indeed, our sector-specific analysis shows differences in wages across workers lead to substantial welfare differences (see table 2).

\footnotetext{
${ }^{15}$ Source: Fondo documental. INEbase/Historia. Instituto Nacional de Estadística. Available at: https://www.ine.es/inebase_historia/inebase_ historia.htm
}

Finally, the discussion about welfare inequality across economic and age groups raises an important point about within-household distribution of resources. If we think that infants welfare is important because it feeds into their parents' well-being, then we need to acknowledge intra-household access to resources. Further research should aim at providing a complete picture of household welfare drawing on economic and health information about its individuals over time, especially if the composition of households changes over time. We reckon such an exercise is very demanding, but this bottom-up approach is crucial to provide a complete picture of a society's level of well-being.

\subsection{Extending the model and robustness tests}

This section provides a more temporally-comprehensive perspective assuming that life expectancy, our main constraint in terms of data, evolved linearly between benchmarks. This exercise, while less robust than our main calculations, is interesting because it allows us to take into account yearly fluctuations in real wages and between-sector wage inequality. Figure 3 presents the results of applying equation 4 to observed annual data on male wages and inequality, and interpolated data on male life expectancy at birth. The four vertical lines indicate the benchmarks considered earlier to ease comparisons with tables 1 and 2 . There are various interesting points. The series for the whole city (thick blue line) closely resembles the development pattern of the calculations for the industrial sector (solid green line). This is not surprising, given the large employment share of this sector in the local economy. As a result, the somewhat more dramatic trends in the agricultural sector have little bearing on the aggregated series.

If we consider the evolution of the series over time, it is interesting to note that the rising trend we identified during the period 1860-1877 mostly took place, assuming mortality fell linearly over time, 1870 when real wages experienced a marked increase. The period 1877-1900, characterized by stagnation as we saw in Table 2, exhibits a great deal of volatility as nominal wages and prices fluctuate over time. Despite these, we observe improving welfare until the mid-1890s, when the index drops dramatically to levels reached in the 1870 s.

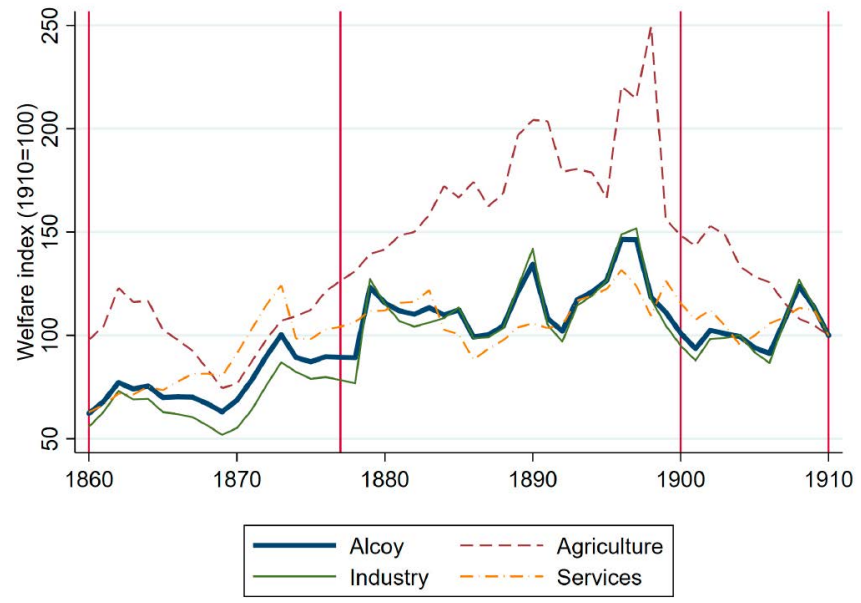

Figure 3. Worker's annual welfare in Alcoy using interpolated values for life expectancy, $1860-1910(1910=100)$.

Note: see Table 1 for the sources. We used equation 4 for the calculations. We used linear interpolation to infer life expectancy between benchmarks. The four vertical lines represent the benchmarks we have considered so far 
Finally, we test the robustness of our results to changes in the calibration of our model. As explained in the methodological section, we use VSLs from the literature to gauge the relative importance of health changes in our utility metric. For our main results, we used an average value suggested in the literature (Gallardo-Albarrán, 2019, pp. 65-66), but it is informative to assess the sensitivity of our trends to changes in the VSL. As upper- and lower-bound ranges we use $\$ 5$ and $\$ 7$ million and present the resulting welfare levels in Table $1 \mathrm{~A}$ (appendix). Intuitively, assuming a higher VSL results in a larger welfare increase, given that mortality decreased substantially during the analyzed period. We do not observe a large difference between the upper-bound and the benchmark series, since the index rises by 40 and 45 percentage points, respectively. Similarly, assuming a lower VSL does not substantially alter our results, since the implied welfare increase becomes 35 percentage points. Thus, we can conclude that workers' welfare -as measured by changes in wages, between-sector inequality and life expectancy- increased between 45 and 35 percentage points.

\section{Conclusions}

This article studies overall living standards in Alcoy, a Spanish pioneer industrial city, during a phase of rapid industrialization between 1860 and 1910 . We have constructed a consumption equivalent metric of living standards drawing on state-of-the-art techniques from welfare economics with highly disaggregated male and female wage data by sector, and information on health.

We derive three main conclusions from our analyses. First, welfare rose by more than 50 percentage points during Alcoy's industrialization, contrary to the more pessimistic picture portrayed by indicators of material living standards. For male workers, most of this improvement took place before 1877 , since welfare stagnated and even declined slightly thereafter. Health was the main driving force of these well-being gains, as life expectancy increased strongly before 1877 and then reached a plateau due to urban congestion and overcrowding. Concerning the well-being of female workers, although these are more tentative due to lack of data, our findings suggest that welfare followed the broad patterns discussed above with the exception that female living standards did not stagnate during the last part of the $19^{\text {th }}$ century.

Some of these trends are in line with recent research on the consequences of industrialization for workers' welfare in England. For instance, Gallardo-Albarrán and de Jong (2021) find decreasing welfare levels during the late eighteenth century due to rising working time and income inequality, despite improving health. On the other hand, we find that welfare levels stagnated when life expectancy gains came to a halt, while real wages in England took the lead when the health status of the population started deteriorating. This suggests that real wages in Alcoy did not fully compensate for the disamenities brought about by industrialization. A further interesting implication of our findings relates to the strong increase in well-being during the Alcoy's industrialization, which contrasts with the experience for some northern European countries.

Our second main conclusion relates to unequal welfare gains across different parts of the population. While workers in agriculture experienced long-term stagnation, the well-being of industrial and service labourers rose by 80 and almost 70 per cent, respectively. This reflects the success of Alcoy's industrial sector and the complex service sector activities that emerged around it. Our welfare measure shows, however, that the increase in value added by these two sectors did not compensate for the increasingly worse living conditions after 1877.

Finally, we find that children's better health conditions first drove aggregate welfare, while the health status of adults (measured by life expectancy at age 15) did so to a much lower extent. Most importantly, we show and quantify the implications of taking different perspectives (infants vs adults) in an analysis of long-term well-being: adults experienced about 50 less welfare growth than children. Excluding the youngest part of the population from the calculations during the analyzed period underestimates overall welfare growth by more than 50 per cent.

The approach we have taken in this article has the advantage of aggregating various well-being dimensions according to the principles of expected utility theory. This can be extended in several ways to gain a further understanding of historical welfare. For instance, we have measured changes in health with a mortality measure (i.e. life expectancy at birth and at age 15) without considering the impact of morbidity on workers' lives. Also, the welfare impact of inequality could be conceptualized more comprehensively by considering other mechanisms. In any case, we view our exercise as an important first step to understand historical well-being in Spain with an approach that has received little attention in this context until now.

\section{Acknowledgements}

This work has been funded by the Ministry of Science, Innovation and Universities, through the project PGC2018097817-B-C32.

\section{Archival material}

Archivo Histórico Municipal de Alcoy. Estadística obrera de empleados y parados por sectores. 25 de octubre de 1914, signatura: 5557/18.

Archivo Histórico Municipal de Alcoy. Interrogatorio sobre las artes, oficios, fábricas de Alcoy. 1803-1804, signatura: 5542

\section{Bibliography}

Aracil, R. and García, M. (1974). Industrialització al País Valencià (el cas d’Alcoi). Valencia: Eliseu Climent.

Aristotle (1990). Éticas nicomáquea y eudemia, traducidas por J. Pallí. Madrid: Editorial Gredos.

Atkinson, A. B. (1970). "On the Measurement of Inequality", Journal of Economic Theory, 2 (3), 244-263.

Barquín, R. (2019). "El consumo urbano en Andalucía Oriental a mediados del siglo xIx", Investigaciones de Historia Económica. Economic History Research, 15, 13-22.

Becker, G. S., Philipson, T. J. and Soares, R. R. (2005). "The quantity and quality of life and the evolution of world inequality", American Economic Review, 95, 277-291.

Beneito, À. (2003). Condicions de vida i salut a Alcoi durant el procés d'industrialització. Valencia: Universitat Politècnica de València. 
Beneito, P. and García-Gómez, J. J. (2019). Gender Earnings Gaps and Gender Mortality Gaps during the Industrialisation: The Case of Alcoy, Spain (1860-1914). Discussion Papers in Economic Behaviour, 01/09. Available at: https://www.erices.es/upload/workingpaper/93_0119.pdf

Cámara, A., Martínez-Carrión, J., Puche, J. and Ramon-Muñoz, J. (2019). "Height and inequality in Spain: a long-term perspective", Revista de Historia Económica. Journal of Iberian and Latin American Economic History, 37, 205-238.

Cerdà, M. (1980). Lucha de clases e industrialización. Valencia: Almudín.

Coloma, R. (1959). La Revolución Internacionalista Alcoyana de 1873 (el petròlio). Alicante: Instituto de Estudios Alicantinos.

Comín, F. Hernández, M. and Llopis, E. (eds.) (2010). Historia económica de España. Siglos X-XX. Barcelona: Crítica.

Costa, D. L. and Kahn, M. E. (2004). "Changes in the value of life, 19401980", The Journal of Risk and Uncertainty, 29, 159-180.

Crafts, N. F. R. (1997). "Some dimensions of the "Quality of Life" during the British industrial revolution", The Economic History Review, 50, 617-639.

Cuevas, J. (1999a). Los orígenes financieros de la industria de Alcoi (17701900) [doctoral dissertation]. Universidad de Alicante.

Cuevas, J. (1999b). "Innovación técnica y estructura empresarial en la industria textil de Alcoi, 1820-1913", Revista de Historia Industrial, $16,13-43$.

Dávila, J. M. (1993). Alcoy: Desarrollo urbano y planeamiento. Alicante: Universidad de Alicante.

Escudero, A. (2002). "Volviendo a un viejo debate: el nivel de vida de la clase obrera británica durante la Revolución Industrial”, Revista de Historia Industrial, 21, 13-60.

Escudero, A. and Pérez Castroviejo, P. (2010). “The living standard of miners in Biscay (1876-1936): wages, the Human Development Index and height", Revista de Historia Económica. Journal of Iberian and Latin American Economic History, 28, 503-534.

Escudero, A. and Simón, H. J. (2012). "Diferencias provinciales de bienestar en la España del siglo xx”, Revista de Historia Industrial, 49, 17-54.

Felice, E., Pujol Andreu, J. and D’Ippoliti, C. (2016). “GDP and life expectancy in Italy and Spain over the long run: A time-series approach", Demographic Research, 35, 813-866.

Fishback, P. (1992). Soft Coal, Hard Choices: The Economic Welfare of Bituminous Coal Miners, 1890-1930. New York; Oxford: Oxford University Press.

Fleurbaey, M. and Blanchet, D. (2013). Beyond GDP: Measuring welfare and assessing sustainability. New York; Oxford: Oxford University Press.

Floud, R., Fogel, R.W., Harris, B. and Chul Hong, S. (2011). The changing body. Health, Nutrition and Human Development in the Western World since 1700. Cambridge: Cambridge University Press.

Gallardo-Albarrán, D. (2019). "Missed opportunities? Human welfare in Western Europe and the United States, 1913-1950", Explorations in Economic History, 72, 57-73.

Gallardo-Albarrán D. and de Jong, H. (2021). "Optimism or pessimism? A composite view on English living standards during the Industrial Revolution", European Review of Economic History, 25 (1), 1-19.

García-Gómez, J. J. (2013). El nivel de vida de los trabajadores de Alcoy (1836-1936) [doctoral dissertation]. Universidad de Alicante.

García-Gómez, J. J. and Salort, S. (2014). "La reforma sanitaria en Alcoi (1836-1914): Industrialización, urbanización, fallos de mercado e intervención pública”, Historia Social, 80, 95-112.

García-Gómez, J. J. (2015). "El nivel de vida de los trabajadores de Alcoy: salarios, nutrición y reforma sanitaria (1836-1913)", Investigaciones de Historia Económica. Economic History Research, 11 (3), 164-173.

García-Gómez, J. J. (2016). “Urban penalty en España: el caso de Alcoy (1857-1930)", Revista de Historia Industrial, 63 (2), 49-78.

García-Gómez, J. J. and Puche, J. (2016). “Reforma sanitaria, salud pública y bienestar biológico durante la industrialización española: el caso de Alcoy, 1840-1915", Asclepio: Revista de Historia de la Medicina y de la Ciencia, 68 (1), 1-17.
García-Gómez, J. J. y Trescastro López, E. (2017). “Transición nutricional, bienestar y salud: el caso de una ciudad industrial, Alcoy (18521928)", Dynamis, 37 (2), 389-411.

García-Gómez, J. J. and Escudero, A. (2018). “The Standard of Living of the Workers in a Spanish Industrial Town: Wages, Nutrition, Life Expectancy and Height in Alcoy (1870-1930)", Social Indicators Research, 140 (1), 347-367.

Harris, B., and Helgertz, J. (2019). "Urban sanitation and the decline of mortality", The History of the Family, 24 (2), 207-226.

Jones, C. I. and Klenow, P. J. (2016). "Beyond GDP? Welfare across countries and time", American Economic Review, 106, 2426-2457.

Klugman, J., Rodríguez, F. and Choi, H.-J. (2011). "The HDI 2010: New controversies, old critiques", The Journal of Economic Inequality, 9 249-288.

Komlos, J. (1993). "The Secular Trend in the Biological Standard of Living in the United Kingdom, 1730-1860", Economic History Review, 46, 115-144.

Madoz, P. (1846). Diccionario Geográfico, Estadístico e Histórico de España y sus posesiones de ultramar, Tomo I, $2^{\mathrm{a}}$ edición. Madrid: Est. Literario-Tipográfico de P. Madoz y L. Sagast.

Martí, J. (1864). Guía del forastero en Alcoy. Alcoy: José Martí Casanova Librero-Editor.

Martínez Carrión, J. M. (2012). “La talla de los europeos, 1700-2000: ciclos, crecimiento y desigualdad", Investigaciones de Historia Económica. Economic History Research, 8, 176-187.

Meier, G. M. (1980). Leading issues in Economic Development. Oxford: Oxford University Press.

Milanovic, B. (2016). Global Inequality. A New Approach for the Age of Globalization. London; Cambridge: Harvard University Press.

Morris, M. D. (1979). Measuring the Condition of the World's Poor. The Physical Quality of Life Index. New York: Overseas Development Council.

Myrdal, G. (1974). “Contribución a una teoría más realista del crecimiento y el desarrollo económico”, Trimestre Económico, 161, $217-$ 229.

Nadal, J. (2003). Atlas de la industrialización de España, 1750-2000. Barcelona: Crítica.

Nicolau, R. (2005). "Población, salud y actividad”, in Carreras, A. and Tafunell, X. (eds.). Estadísticas históricas de España (siglos XIX y XX). Bilbao: Fundación BBVA, pp. 77-154.

Norhdaus, W. D. and Tobin, J. (1973). “Is Growth Obsolete?", in Moss, M. (ed.). The measurement of economic and social performance. New York: National Bureau of Economic Research, pp. 509-564.

Nordhaus, W. D. (2003). "The health of nations: The contribution of improved health to living standards", in Murphy, K. M. and Topel, R. H. (eds.). Measuring the gains from medical research: An economic approach. Chicago: University of Chicago Press, pp. 9-40.

Parejo, A. (2006). "De la región a la ciudad: hacia un nuevo enfoque de la historia industrial española contemporánea”, Revista de Historia Industrial, 30, 53-101.

Piketty, T. (2014). Capital in the Twenty-First Century. London; Cambridge: Harvard University Press.

Prados de la Escosura, L. (2015). "World human development: 18702007", Review of Income and Wealth, 61 (2), 220-247.

Ravallion, M. (2012). "Troubling tradeoffs in the Human Development Index", Journal of Development Economics, 99, 201-209.

Real Academia de Medicina (1879). Anales de la Real Academia de Medicina. Tomo I, Cuaderno I. Madrid: Imprenta y fundición de Manuel Tello.

Revenga, R. (1904). La muerte en España: un estudio estadístico sobre la mortalidad. Madrid: Prensa de Madrid.

Sen, A. (1987). Standard of Living. New York: Cambridge University Press.

Stiglitz, J. E. (2012). The price of inequality: How today's divided society endangers our future. New York: WW Norton \& Company.

Stiglitz, J. E., Sen, A. and Fitoussi, J. P. (2009). Report by the Commission on the Measurement of Economic Performance and Social Progress. Paris: OECD.

Szreter, S. and Mooney, G. (1998). "Urbanisation, mortality and the standard of living debate: new estimates of the expectation of life 
at birth in nineteenth-century British cities", Economic History Review, 51, 84-112.

Torró, Ll. (1994). “Los inicios de la mecanización de la industria lanera en Alcoi”, Revista de Historia Industrial, 6, 133-141.

Torró Gil, Ll. (1996). "Al voltant dels orígens de la industrialització valenciana", in Azagra, J. et al. (eds.). De la sociedad tradicional a la economía moderna. Estudios de Historia Valenciana Contemporánea. Alicante: Instituto de cultura Juan Gil-Albert, pp. 34-61.

Torró Gil, Ll. (2000). "Protoindústria i acumulació originària de capital (Alcoi, 1430-1823)", Revista Eines, 18, 3.

Torró Gil, Ll. (2004). "Procedimientos técnicos y conflictividad gremial: el ancho de los peines de los telares alcoyanos (1590-1797)", Revista de Historia Industrial, 25, 165-184.

Torró Gil, Ll. (2020). "Economic crises and industrialisation in Southern Europe: the Valencian cloth-making town of Alcoi (1600 and 1800)", Revista de Historia Industrial, 80, 85-117.

United Nations Development Program-UNDP (1990). Human development report 1990. New York: Oxford University Press.

\section{Appendix}

\section{Table 1A.}

Robustness test using different calibrations to value health changes

\begin{tabular}{lccc}
\hline & Benchmark & Upper-bound & Lower-bound \\
\hline Year & (I) & (II) & (III) \\
\hline 1860 & 60 & 55 & 65 \\
\hline 1877 & 93 & 92 & 94 \\
\hline 1900 & 99 & 97 & 101 \\
\hline 1910 & 100 & 100 & 100 \\
\hline
\end{tabular}

Note: see Table 1 for the sources. We used equation 4 for the calculations. Column I was taken from Table 2, column I in Panel A. Column II and III present welfare indices using a VSL of $\$ 5$ and $\$ 7$ million to calibrate in equation 4.
Usher, D. (1973). "An imputation to the measure of economic growth for changes in life expectancy", in Moss, D. (Ed.). The measurement of economic and social performance. New York: National Bureau of Economic Research, pp. 193-223.

Varea, C., Sánchez-García, E., Bogin, B., Ríos, L., Gómez-Salinas, B., López-Canorea, A. and Martínez-Carrión, J. M. (2019). “Disparities in Height and Urban Social Stratification in the First Half of the 20th Century in Madrid (Spain)", International Journal of Environmental Research and Public Health, 16 (11), 2048.

Voth, H. J. (2004). "Living standards and the urban environment”, in Floud, R. and Johnson, P. (eds). The Cambridge Economic History of Modern Britain.Volume 1: Industrialisation, 1700-1860. Cambridge: Cambridge University Press, pp. 268-294.

Williamson, J. G. (1984). "British mortality and the value of life", Population Studies, 38(1), 157-172.

Wrigley, E. A., Davies, R. S., Oeppen, J. E. and Schofield, R. S. (1997). English population history from family reconstitution 1580-1837. Cambridge: Cambridge University Press. 